\title{
Molecular and cellular actions of a structural domain of human growth hormone (AOD9401) on lipid metabolism in Zucker fatty rats
}

\section{F M Ng, W J Jiang, R Gianello, S Pitt and P Roupas ${ }^{1}$}

Department of Biochemistry and Molecular Biology, Monash University, Clayton, Victoria 3168, Australia

${ }^{1}$ Department of Clinical Biochemistry, Royal Children's Hospital, Parkville, Melbourne, Victoria 3052, Australia

(Requests for offprints should be addressed to F M Ng, Department of Biochemistry and Molecular Biology, Faculty of Medicine, Monash University, Clayton, Victoria 3168, Australia;

Email: frank.ng@med.monash.edu.au)

(P Roupas is currently at CSIRO, Private Bag 16, Werribee, Victoria 3030, Australia)

\begin{abstract}
A lipolytic domain (AOD9401) of human growth hormone $(\mathrm{hGH})$ which resides in the carboxyl terminus of the molecule and contains the amino acid residues 177-191, has been synthesized using solid-phase peptide synthesis techniques. AOD9401 stimulated hormone-sensitive lipase and inhibited acetyl coenzyme A carboxylase (acetyl CoA carboxylase) in isolated rat adipose tissues, in a similar manner to the actions of the intact hGH molecule. The synthetic lipolytic domain mimicked the effect of the intact growth hormone on diacylglycerol release in adipocytes. Chronic treatment of obese
\end{abstract}

Zucker rats with AOD9401 for 20 days reduced the body weight gain of the animals, and the average cell size of the adipocytes of the treated animals decreased from 110 to $80 \mu \mathrm{m}$ in diameter. Unlike hGH, synthetic AOD9401 did not induce insulin resistance or glucose intolerance in the laboratory animals after chronic treatment. The results suggest that AOD9401 has the potential to be developed into a therapeutic agent for the control of obesity.

Fournal of Molecular Endocrinology (2000) 25, 287-298

\section{INTRODUCTION}

A recent article on the history of growth hormone (Tattersall 1996) clearly reveals the fascination of the growth hormone $(\mathrm{GH})$ molecule to numerous investigators over a long period of time. In the early 1960s, a working party of the Pituitary Hormone Committee of the UK Medical Research Council was established to initiate clinical trials of human (h) GH (Raben 1962). Pituitary hGH was used for the treatment of patients with short stature in the late 1960s until the early 1980s. The clinical applications of pituitary hGH were greatly reduced from the mid 1980s due to the possible transmission of the Creutzfeldt-Jacob disease (CJD). Meanwhile, the introduction of recombinant-hGH (Martial et al. 1979) has changed the whole field of hGH research and applications. hGH was the second human hormone to be produced commercially using recombinant DNA technology. With large-scale production, the supply of hGH no longer restricts the types and number of human therapies. However, the complexity of the molecular mechanism of the hormonal actions is not yet fully understood. It is essential to have a better insight into its molecular actions for the efficient and safe applications to human use. This study focused on the lipolytic property of $\mathrm{hGH}$ and the potential role of the lipolytic fragment of hGH for the treatment of obesity.

A wide spectrum of cellular and metabolic activities of hGH has long been documented (Strobl \& Thomas 1994). The hormone regulates somatic growth through hypertrophy and hyperplasia as a result of tissue differentiation and cell proliferation. Exogenous hGH also stimulates protein synthesis 
and lipolysis and modulates carbohydrate metabolism and fluid-electrolyte balance. Our studies with genetically growth hormone-deficient mice also demonstrated the anti-lipogenic action of the exogenous hormone (Adamafio \& Ng 1984). It has generally been recognized that hGH exerts a profound effect on body composition (Brummer \& Bengtsson 1995). Systemic hGH administration reduces body fat mass as well as fat distribution (Rosenbaum et al. 1989, Bengtsson et al. 1992). The use of hGH for the treatment of human obesity has not been advocated due to serious side effects, including glucose intolerance, insulin resistance, sodium retention, hypertension, edema and carpal tunnel syndrome (Daughaday \& Harvey 1994).

Human GH has a history as a lipolytic hormone dating back to the discovery by Lee and Schaeffer (1934) of decreased carcass lipid in rats treated with growth-promoting extract of anterior pituitary glands. However, the molecular mechanism of the lipolytic action of this multifunctional protein hormone is not fully elucidated at present. The concept that a large multifunctional protein might contain a number of discrete functional domains for a variety of specific biochemical or physiological actions (Palidini et al. 1979, Chretien 1999) led us to investigate the various functional domains of $\mathrm{hGH}$. We first reported that the amino-terminus of the $\mathrm{hGH}$ molecule is the functional domain for the insulin-like action of the hormone ( $\mathrm{Ng} 1990)$. The concept was further supported by the observations of Jeoung et al. (1993) and Lopez-Guajardo et al. (1998) that the sequence containing residues 108-129 might be the mitogenic domain of the hormone, and is consistent with the early observation of Liberti (1981) that the hormonal fragment 87-124 generated somatomedin-like activity. We have identified the metabolic domain responsible specifically for the lipolytic/antilipogenic activity of the $\mathrm{hGH}$ molecule. It resides in the hGH sequence containing the amino acid residues 177-191 and is referred to by us as AOD9401. Nuclear magnetic resonance (NMR) studies revealed that AOD9401 in solution retains a cyclic loop structure, similar to the conformational feature of the structural domain in the intact hGH molecule (Ogru et al. 2000).

Our preliminary studies showed that AOD9401 reduced by more than $20 \%$ the body weight gain of C57BL/6J (ob/ob) mice after intraperitoneal injections at a daily dose of $200 \mu \mathrm{g} / \mathrm{kg}$ body weight for 18 days (Natera et al. 1994). We now report the in vitro and in vivo activities of AOD9401 in fatty Zucker rats, demonstrate the molecular mechanism of the metabolic events and provide supporting evidence for the development of AOD9401 or an analogue thereof as a specific and safe therapeutic agent for the treatment of human obesity.

\section{MATERIALS AND METHODS}

\section{Preparation of synthetic peptide analogues}

The hGH sequence containing the amino acid residues 177-191 (AOD9401) was prepared using solid-phase peptide synthesis methodology. $\mathrm{N}^{\alpha}-9-$ fluorenylmethoxycarbonyl (Fmoc) chemistry was used for peptide synthesis. The peptides were purified with reversed-phase high performance liquid chromatography (RP-HPLC) and characterized for their purity, amino acid composition, and molecular weight with analytical RP-HPLC, amino acid analysis, and mass spectroscopy respectively.

\section{Experimental animals}

Obese Zucker (fa/fa) rats (Zucker \& Zucker 1961) of both sexes, aged 15-16 weeks were fed on normal chow pellets (Clark King, Melbourne, Australia) consisting of $67 \%$ carbohydrate, $20 \%$ protein and $6 \%$ fat (the residue was crude fibres and minerals). Food and drinking water were available ad libitum. The animals were individually housed in plastic cages under the care of the animal technicians and were kept at an ambient temperature of $22{ }^{\circ} \mathrm{C}$ with a 12-h light/darkness cycle in the Department of Biochemistry and Molecular Biology, Monash University. The protocols for experiments on laboratory animals were approved by the Animal Ethics Committee of Monash University. The NHMRC Australian Code of Practice for the care and use of animals for scientific purposes (1997) was observed at all times.

\section{Assays for acetyl-CoA carboxylase and hormone-sensitive lipase}

The acetyl-CoA carboxylase activity was measured by determining the rate of carboxylation of acetyl-CoA with $\left.\mathrm{H}^{14}{ }^{14} \mathrm{C}\right] \mathrm{O}_{3}$ into $\left[{ }^{14} \mathrm{C}\right]$ malonyl$\mathrm{CoA}\left[{ }^{14} \mathrm{C}\right]$ bicarbonate ( $\mathrm{Ng} \&$ Heng 1988). Isolated adipocytes were preincubated at $37^{\circ} \mathrm{C}$ for $30 \mathrm{~min}$ in

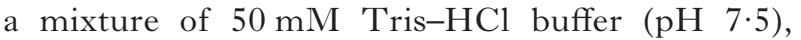
$10 \mathrm{mM}$ potassium citrate, $10 \mathrm{mM} \mathrm{MgCl}_{2}, 1 \mathrm{mM}$ dithiothreitol (DTT), and BSA $(0.8 \mathrm{mg} / \mathrm{ml})$. The reaction was then initiated by adding an aliquot of the cell suspension to $0.5 \mathrm{ml}$ assay mixture containing also $3.75 \mathrm{mM}$ ATP, $0.125 \mathrm{mM}$ acetyl$\mathrm{CoA}$, and $12 \cdot 5 \mathrm{mM} \quad \mathrm{NaH}\left[{ }^{14} \mathrm{C}\right] \mathrm{O}_{3}$ (final specific 
activity $0.44 \mu \mathrm{Ci} / \mu \mathrm{mol})$. After incubation at $37^{\circ} \mathrm{C}$ for $10 \mathrm{~min}$, the reaction was terminated with the addition of $0.1 \mathrm{ml} \quad 6 \mathrm{M} \mathrm{HCl}$. The unreacted $\mathrm{NaH}\left[{ }^{14} \mathrm{C}\right] \mathrm{O}_{3}$ was removed and $\left[{ }^{14} \mathrm{C}\right]$ malonyl CoA was determined with a Wallac 1410 liquid scintillation counter. The specific activity of the enzyme was expressed as $\mathrm{U} / \mathrm{mg}$ protein, where $1 \mathrm{U}$ acetylCoA carboxylase was defined as that amount of enzyme which catalyzed the carboxylation of 1 nmole acetyl-CoA per min under the assay conditions described.

Hormone-sensitive lipase (HSL) activity of isolated adipocytes was evaluated by measuring the rate of hydrolysis of $\left[{ }^{14} \mathrm{C}\right]$ trioleic acid according to the method of Stralfors et al. (1987). The HSL activity of adipocytes was measured at $37^{\circ} \mathrm{C}$ for $1 \mathrm{~h}$ in a final volume of $200 \mu \mathrm{l}$, containing $10 \mu \mathrm{mol}$ phosphate buffer (pH 7.0), $15 \mu \mathrm{mol}$ emulsified $\left[{ }^{14} \mathrm{C}\right]$ triolein, and $10^{8}$ cells. The reaction was stopped by adding $1 \mathrm{ml}$ of the fatty acid extraction mixture of chloroform-methanol-benzene (2:2:4, $\mathrm{v} / \mathrm{v} / \mathrm{v})$ containing $50 \mu \mathrm{g}$ oleic acid, followed by the addition of $67 \mu \mathrm{l} 0.5 \mathrm{M} \mathrm{NaOH}$. The $\left[{ }^{14} \mathrm{C}\right]$ radioactivity was measured with a Wallac 1410 liquid scintillation counter. The HSL activity was expressed as $\mathrm{U} / \mathrm{mg}$ protein, where the release of $1 \mathrm{nmol}$ of oleic acid per $\mathrm{h}$ was defined as $1 \mathrm{U}$ enzyme activity. Cellular protein was determined with a modified method of Bradford (1976) using the commercially available BCA (bicinchoninic acid) Protein Assay Kit (\#23225x; Pierce, Rockford, IL, USA).

\section{Assays for free fatty acid, glycerol and diacylglycerol release}

A colorimetric assay (Noma et al. 1973) was used for the determination of free fatty acid (FFA) from the incubation medium or plasma from animals. A $100 \mu \mathrm{l}$ sample from incubation medium or plasma for FFA assay was placed in a $10 \mathrm{ml}$ plastic centrifuge tube and then extracted by adding $3 \mathrm{ml}$ organic solvents containing chloroform-heptanemethanol (49:49:2, v/v/v) and followed by $1 \mathrm{ml}$ copper reagent. After mixing, the colour of the solution changed from yellow to greenish blue. The FFA concentration in the sample was determined by reading the absorbance at $610 \mathrm{~nm}$ from the standard curve of known FFA quantities (0$0 \cdot 100 \mu \mathrm{mol}$ ), where palmitic acid (hexadecanoid acid) was used as the standard FFA.

Glycerol concentration in incubation medium or animal plasma was determined by an enzymatic method with glycerol kinase, pyruvic kinase and lactate dehydrogenase. Samples from incubation medium or blood plasma were placed into $10 \mathrm{ml}$ plastic centrifuge tubes and deproteinized with an equal volume of $10 \%$ trichloroacetic acid (TCA), followed by centrifugation for $8 \mathrm{~min}$ at 2600 $\mathrm{rev} / \mathrm{min}(\mathrm{speed}=5 \cdot 5)$ at $4{ }^{\circ} \mathrm{C}$ using a DuPont Sorvall RT-6000 refrigerated centrifuge. After centrifugation, the solution in each sample was separated into two layers and the upper, clear supernatant was transferred into a $40 \mathrm{ml}$ glass test tube with a glass stopper. The solution was then extracted twice with a fivefold excess of ether $(20 \mathrm{ml} \times 2$, $2 \mathrm{~min})$ to remove TCA. The ether was then removed from the extract solution under vacuum overnight and the glycerol concentration was determined using the enzymatic method of McGowan et al. (1983).

Diacylglycerol (DAG) released into the incubation medium was determined with a radioenzymatic assay (Amersham, Castle Hill, NSW, Australia) employing Eschericia coli DAG kinase. Mixed micelle conditions were defined to solubilize DAG from the samples incubated with AOD9401. To each sample taken at different times, E. coli DAG kinase was used to start the assay and its quantitative conversion to $\left[{ }^{33} \mathrm{P}\right]$ phosphatidic acid in the presence of $\left[{ }^{33} \mathrm{P}\right] \gamma$-ATP was allowed. A number of extraction steps were used to remove the unreacted $\left[{ }^{33} \mathrm{P}\right] \gamma$-ATP. Separation of $\left[{ }^{33} \mathrm{P}\right]$ phosphatidic acid was achieved with the use of a $1 \mathrm{ml}$ AmPrep minicolumn. The fractions containing the $\left[{ }^{33} \mathrm{P}\right]$ phosphatidic acid were collected, pooled and counted for radioactivity.

\section{$\left[{ }^{14} \mathrm{C}\right]$ Glucose incorporation into $\left[{ }^{14} \mathrm{C}\right]$ lipid}

The rate of incorporation of exogenous $\left[{ }^{14} \mathrm{C}\right]$ glucose into total lipid in isolated adipose tissue was measured and used as an index of lipogenic activity (Salem \& Wolff 1989, Harris et al. 1993, Natera et al. 1994). Tissues were preincubated in $2 \mathrm{ml}$ Krebs-Ringer bicarbonate (KRB) buffer ( $\mathrm{pH} 7 \cdot 4$ ) containing $40 \mathrm{mg}$ defatted BSA and $0 \cdot 2 \mathrm{mg}$ glucose. Samples were placed in the incubator under an atmosphere of carbogen $\left(95 \% \mathrm{O}_{2} / 5 \% \mathrm{CO}_{2}\right)$ for $1 \mathrm{~h}$ at $37{ }^{\circ} \mathrm{C}$. After preincubation, each tissue was transferred to another flask which contained $2 \mathrm{ml}$ fresh solution of the same composition, as well as $\left[{ }^{14} \mathrm{C}\right]$ glucose (final specific activity $0 \cdot 05 \mu \mathrm{Ci} / \mu \mathrm{mol}$ ), bovine insulin $(0 \cdot 1 \mathrm{mU} / \mathrm{ml})$ and in the presence or absence of AOD9401, and was incubated for a further $90 \mathrm{~min}$. Tissues were then removed from flasks and extracted with $5 \mathrm{ml}$ chloroform-methanol $(2: 1, \quad v / v)$. The $\left[{ }^{14} \mathrm{C}\right]$ lipid of each sample was measured with a Wallac 1410 liquid scintillation counter. The rate of total lipid synthesis was expressed as $\mu \mathrm{mol}\left[{ }^{14} \mathrm{C}\right]$ glucose incorporated into $\mathrm{lipid} / \mathrm{mg}$ tissue/min. 


\section{Determination of blood glucose}

Blood samples $(25 \mu \mathrm{l})$ from experimental animals were collected into heparin-coated tubes. The whole blood glucose level in each sample was measured immediately using a YSI Model-2300 STAT Glucose Analyzer (Yellow Springs Instrument Co., Yellow Springs, OH, USA) with an immobilized glucose oxidase methodology.

\section{Adipocyte isolation and cell size determination}

Adipocytes were isolated from the epididymal fat pads of male Zucker fatty (fa/fa) rats $(200-300 \mathrm{~g}$ ) according to the method described by Roupas et al . (1990). The number of isolated adipocytes was estimated by counting an aliquot of a predetermined volume of cells on a microscope slide, according to a modification of the method by Gliemann (1965). The isolated cells were suspended in KRB buffer prior to use for enzyme assays or cell size determinations.

Prior to cell size determination, the isolated adipocytes were fixed with formalin for $30 \mathrm{~min}$. Centrifugation at 300 r.p.m. at $4{ }^{\circ} \mathrm{C}$ for 1 min was used to separate the formalin from the cells. This procedure allowed the cells to retain their original spherical shape. Aliquots of the fixed cells were placed onto microscope slides and the cell size of adipocytes was determined using a microscope (Nikon, Optiphot Biological Microscope, Tokyo, Japan). The image of the adipocytes was captured under constant illumination, teleconverted, amplified, digitized, and finally displayed on the colour monitor by the Microcomputer Imaging Devise (MCID) system (Imaging Research Inc, St Catharines, Ontario, Canada) with M4 software (version $2 \cdot 1$ 1996). The diameters of cell sizes were recorded and the mean and standard deviation were automatically measured in $\mu \mathrm{m}$ after being calibrated with standard length parameters.

\section{Administration of AOD9401 to Zucker rats}

AOD9401 was administrated to the animals either intraperitoneally (Waynforth \& Flecknell 1992) or intravenously. The intraperitoneal injection was administered to the lower left quadrant of the abdomen in the rat. The femoral vein and jugular vein were the two major sites used for the intravenous injection and clamp experiments with the rat under anaesthesia (Kraegen et al. 1983).

Slow-release AOD9401 tablets or the placebo formulated according to the method of Cardamone et al. (1998) were implanted under the skin layer on either side of the lower quadrant of the abdomen.
Mishel wound clips (9 mm. Mikron AUTOCLIP ${ }^{\circledR}$; Becton Dickinson and Compamy, Sparks, MD, USA) were used to fasten the skin layer, and antibiotic powder (Cicatrin) was applied over the region in order to prevent infection. After surgery, the animals were placed in a cage, and regular inspection by the animal technician was made until consciousness was regained.

\section{Determination of insulin sensitivity of Zucker rats using the clamp technique}

For this preliminary long-term study, four Zucker rats were given daily an intraperitoneal injection of AOD9401 or saline. On the day of the clamp experiment, the animals were anaesthetized intraperitoneally with pentobarbitone $(50 \mathrm{mg} / \mathrm{kg}$ body weight). An intravenous Silastic catheter (Dow Corning, 0.02 inch ID $\times 0.037$ inch OD) was inserted into the right jugular vein for glucose infusion and a second catheter was put into the left carotid artery for blood sampling. During the experiment, blood samples were taken every 4 min from the carotid artery of each animal and their blood glucose levels were determined with an automated YSI glucose analyzer.

The basal level of blood glucose $\left(\mathrm{G}_{0}\right)$ was determined by averaging the readings of the samples taken at time $0,4,8$, and $12 \mathrm{~min}$. The in vivo experiment was then started by infusing the glucose-isotonic saline solution $(30 \%, \mathrm{w} / \mathrm{v})$ into each animal via the jugular vein using a peristaltic pump (Minipulse III) at a constant rate of $16.4 \mathrm{mg}$ glucose $/ \mathrm{kg} / \mathrm{min}$, according to previous studies in our laboratory (Jiang 1999). A stabilized steady-state blood glucose level $\left(G_{1}\right)$ was achieved through the negative feedback of endogenous insulin. The $G_{1}$ was maintained for $20 \mathrm{~min}$ and the animal was then given isotonic saline with insulin $(1 \mathrm{U} / \mathrm{ml})$ by infusion via the jugular vein at a constant rate of $4.8 \mathrm{mU}$ insulin $/ \mathrm{kg} / \mathrm{min}$. The blood glucose level was again stabilized and regarded as the second steady-state glucose level $\left(G_{2}\right)$ of the animal. The basal and the two steady-state blood glucose levels were used to determine the glucose utilization and insulin responsiveness of the animals. The difference in these levels between the two groups was used as physiological evidence to determine whether or not chronic treatment with AOD9401 affected carbohydrate metabolism by inducing insulin resistance.

\section{Statistical analysis}

All data are expressed as the mean \pm s.E.M. The difference between two samples was analyzed with 
the Student's $t$-test (Chase 1987). $P$ values of $<0.05$ are accepted as statistically significant.

\section{RESULTS}

\section{In vitro effects of AOD9401 on lipid metabolism in isolated adipocytes}

In the initial studies of the in vitro effects of AOD9401 on lipid metabolism, its effect on the activities of the enzymes acetyl-CoA carboxylase and HSL in isolated adipocytes was examined. Table 1 indicates that both AOD9401 and hGH exerted similar effects and significantly reduced the acetyl-CoA carboxylase activity in a dose-dependent manner over the range of $0 \cdot 1$ to $10 \mu \mathrm{M}$ of the tested substances. The basal level of acetyl-CoA carboxylase activity in rat adipocytes was $0 \cdot 865 \pm 0 \cdot 025$ $\mathrm{U} / \mathrm{mg}$ protein. The maximum inhibitory effect on the enzyme activity was observed when cells were treated with $10 \mu \mathrm{M}$ AOD9401 $(0 \cdot 544 \pm 0 \cdot 018 \mathrm{U} / \mathrm{mg}$ protein, about $37 \%$ reduction from the basal enzyme activity).

The activity of HSL was increased by AOD9401 or hGH over the range $0 \cdot 1$ to $10 \mu \mathrm{M}$ (Table 1 ). The basal HSL activity in the rat adipocytes was $24 \cdot 8 \pm 0.4 \mathrm{U} / \mathrm{mg}$ protein. The increase in enzyme activity was dose-dependent with a maximum response, $32 \cdot 3 \pm 0.8 \mathrm{U} / \mathrm{mg}$ protein, at a dose of $10 \mu \mathrm{M}$ AOD9401.

Biphasic release of diacylglycerol induced by hGH is well established (Roupas \& Herington 1994). AOD 9401 mimicked the effect of hGH on diacylglycerol release in adipocytes at the same molar concentration as hGH $(0 \cdot 45 \mathrm{nM})$. These data in Fig. 1 suggest that some similar signalling steps may be involved in mediating the lipid metabolic effects of AOD9401 and hGH.

\section{In vitro effect of AOD9401 on adipose tissues}

The acute in vitro effects of AOD9401 on lipid metabolism were further assessed at the tissue level by examining the rates of lipogenesis and lipolysis using isolated rat adipose tissue. The effect of AOD9401 on lipogenesis was determined by measuring the rate of incorporation of $\left[{ }^{14} \mathrm{C}\right]$ glucose into lipid in isolated adipose tissues. Table 2 shows that AOD9401 at a concentration of $1 \mu \mathrm{M}$ reduced the rate of lipogenesis in adipose tissue from the basal level, $4 \cdot 05 \pm 0 \cdot 22 \mathrm{pmol} / \mathrm{mg}$ tissue $/ \mathrm{min}$, to $2 \cdot 30 \pm 0 \cdot 15 \mathrm{pmol} / \mathrm{mg}$ tissue $/ \mathrm{min}$. At $10 \mu \mathrm{M}$, AOD9401 was able to achieve a $57 \%$ inhibition of lipid synthesis. This was consistent with its effect on acetyl-CoA carboxylase in which $43 \%$ reduction of enzyme activity was observed.

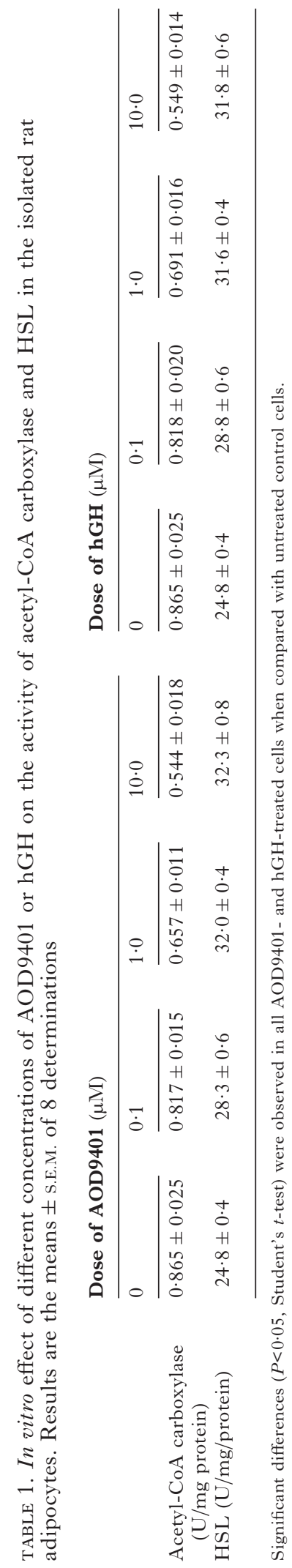

www.endocrinology.org

Fournal of Molecular Endocrinology (2000) 25, 287-298

Downloaded from Bioscientifica.com at $04 / 26 / 2023$ 11:15:25AM 


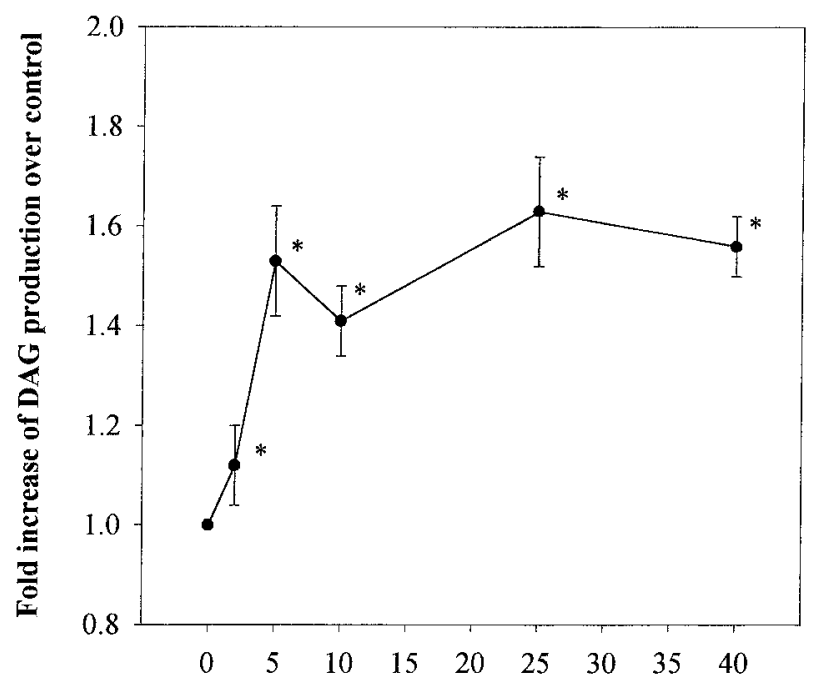

Time (minutes)

FIGURE 1. In vitro effect of AOD9401 on the production of a secondary messenger molecule, DAG. The time course study was conducted to measure the release of DAG from isolated adipocytes during incubation in the presence of $0.45 \mathrm{nM}$ AOD 9401 . Results are means \pm s.E.M. of 8 determinations. $* P<0 \cdot 05$ compared with the basal level at zero time (Student's $t$-test).

AOD9401 also exerted lipolytic effects on isolated adipose tissue in a dose-dependent manner over the range 0 to $1 \cdot 0 \mu \mathrm{M}$. The basal rate of glycerol release was $9 \cdot 50 \pm 0 \cdot 50 \mathrm{pmol} / \mathrm{mg}$ tissue $/ \mathrm{min}$. In the presence of $0 \cdot 1 \mu \mathrm{M}$ AOD 9401, the glycerol level was increased to $13 \cdot 17 \pm 1.00 \mathrm{pmol} / \mathrm{mg}$ tissue $/ \mathrm{min}$ and with $10 \mu \mathrm{M}$ AOD9401 it was increased to $15 \cdot 00 \pm 1 \cdot 17 \mathrm{pmol} / \mathrm{mg}$ tissue $/ \mathrm{min}$. However, no further stimulation of lipolytic action was observed when the peptide concentration was increased over $10 \mu \mathrm{M}$. The ratios of released FFAs to glycerol among samples in the test group were much less than 3 , the theoretical value, and decreased when the concentration of AOD9401 was increased. These observations were attributed to the fact that some of the released FFAs might have been oxidized or re-esterified into triglycerides by the adipose tissue (Campbell et al. 1994)

\section{In vivo effect of AOD9401 on adiposity of Zucker rats}

The body weights of obese Zucker rats implanted with slow-release AOD9401 at a dose of $450 \mu \mathrm{g} / \mathrm{kg}$ body weight/day were monitored for 20 days. Results in Fig. 2 clearly indicate that a significant effect of AOD9401 on the reduction of body weight gain became evident by day 8 and continued up to the end of the experiment on day 20. However, Zucker rats which received daily intraperitoneal injections of AOD9401 under similar experimental conditions usually had a $7-10 \%$ reduction in their body weight compared with the untreated control animals. This modulation of body weight gain was due, at least in part, to the reduction of body fat mass, as the ex vivo studies of the adipose tissues of the treated animals revealed the inhibition of the lipogenic activity by AOD9401 (Fig. 3). The average cell size of the adipocytes of the AOD9401 treated animals was reduced from approximately 110 to $80 \mu \mathrm{m}$ in diameter (Fig. 4). Fewer adipocytes with a diameter over $110 \mu \mathrm{m}$ were found in the treated animals than in the untreated obese controls (Fig. 5). These findings are consistent with previous observations in which the long-term intraperitoneal administration of AOD9401 reduced the adiposity of obese mice (Natera et al. 1994).

\section{Acute effect of AOD9401 on basal blood glucose of Zucker rats}

The basal blood glucose level of non-fasted Zucker fatty rats was $7 \cdot 8 \pm 0 \cdot 8 \mathrm{mM}$. There was no significant change in circulating levels of blood glucose following a bolus intravenous injection of AOD9401 $(250 \sim 1000 \mu \mathrm{g} / \mathrm{kg})$ to the animals (Table 3). Although animals showed a small acute response to AOD9401 at $1000 \mu \mathrm{g} / \mathrm{kg}$, the highest dose tested in this study, the hyperglycaemic effect of AOD9401 was only marginal $(0 \cdot 6 \pm 0 \cdot 3 \mathrm{vs}$ $0 \cdot 1 \pm 0 \cdot 2 \mathrm{mM}, \quad 30 \mathrm{~min}$ after administration) and quickly returned to basal levels within $3 \mathrm{~h}$. These observations were different from those reported in previous studies $(\mathrm{Ng} \&$ Bornstein 1978, Wade et al. 1982). The difference was probably due to the purity of the peptide preparations. However, the transient hyperglycaemic actions of hGH(177-191) peptide used in the earlier reports were also diminished within one hour.

\section{Chronic effect of AOD9401 on glucose tolerance and insulin resistance}

Glucose tolerance and insulin responsiveness of the treated Zucker rats were determined and compared with those of saline-treated controls, using the clamp technique (Coates et al. 1995, Morris et al. 1997). The results revealed that there were no significant differences in glucose tolerance or insulin responsiveness between the treated group and the control group of animals under the present experimental conditions (Table 4). 
TABLE 2. In vitro effect of AOD9401 on the rates of lipogensis and lipolysis in isolated rat adipose tissues. The tissues were incubated in the buffer without or with AOD9401 at different concentrations, and the rates of glucose incorporated into lipid (lipogenesis) and glycerol released from triglyceride (lipolysis) were measured. Results are the means \pm s.E.M. of 12 determinations

Rate of glucose incorporated into lipid (pmol/mg tissue/min)

Release of glycerol (pmol/mg tissue $/ \mathrm{min}$ )

Dose of AOD9401 $(\mu \mathrm{M})$

\begin{tabular}{|c|c|c|c|}
\hline 0 & $0 \cdot 1$ & 1 & 10 \\
\hline $4 \cdot 05 \pm 0 \cdot 22$ & $3 \cdot 55 \pm 0 \cdot 15$ & $2 \cdot 30 \pm 0 \cdot 15$ & $2 \cdot 21 \pm 0 \cdot 18$ \\
\hline $9 \cdot 50 \pm 0 \cdot 50$ & $13 \cdot 17 \pm 1 \cdot 00$ & $15 \cdot 50 \pm 0 \cdot 67$ & $15 \cdot 00 \pm 1 \cdot 17$ \\
\hline
\end{tabular}

Significant differences $(P<0 \cdot 05$, Student's $t$-test) were observed between the presence and absence of AOD9401 in all cases.

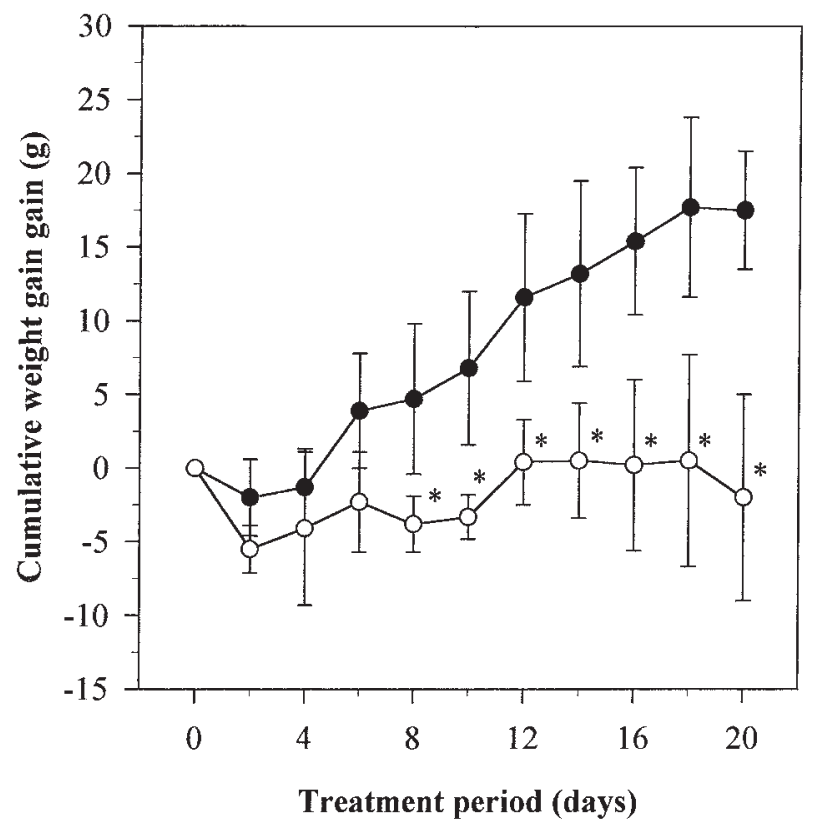

FIGURE 2. Effect of chronic treatment with AOD9401 on cumulative body weight gain in Zucker ( $\mathrm{fa} / \mathrm{fa}$ ) rats. Animals were treated by implantation of either placebo control (@) or AOD9401 (O) tablets at a dose of $450 \mu \mathrm{g} / \mathrm{kg}$ body weight per day. Results are means \pm S.E.M. of 4 animals in each group. $* P<0 \cdot 05$ compared with the control group (Student's $t$-test).

The basal blood glucose level $\left(\mathrm{G}_{0}\right)$ was calculated by averaging the first four blood samples taken over the 0 to 12 th minute. The $G_{0}$ values after the 28 -day treatment with saline or AOD9401 at a dose of $500 \mu \mathrm{g} / \mathrm{kg} / \mathrm{day}$, were $8 \cdot 3 \pm 0 \cdot 1 \mathrm{mmol} / 1\left(\mathrm{G}_{0}\right)$ in the treated group and $10 \cdot 4 \pm 2 \cdot 5 \mathrm{mmol} / \mathrm{l}\left(\mathrm{G}_{0}\right)$ in the control group. The first steady-state blood glucose level $\left(G_{1}\right)$ was calculated from the average of six blood samples taken from the 28 th to 48 th minute. This elevated blood glucose level, resulting from the infusion of exogenous glucose, is an in vivo physiological parameter of the animals which

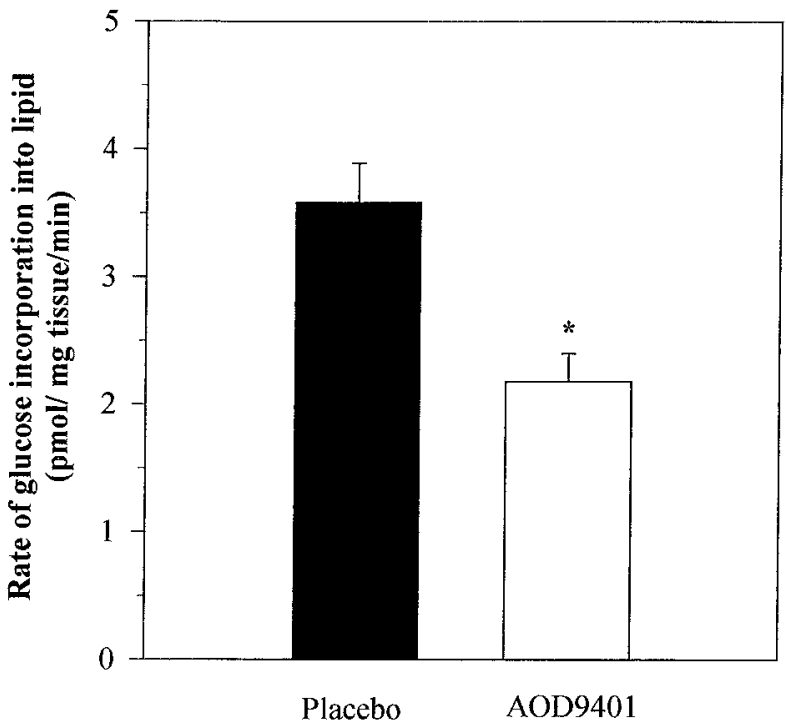

Treatment

FIGURE 3. Ex vivo effect of AOD9401 on the rate of lipid synthesis in adipose tissue isolated from animals after treatment as described in the legend to Fig. 2. Results are means \pm s.E.M. of 12 determinations from 4 animals. $* P<0 \cdot 05$ compared with the control (placebo) group (Student's $t$-test).

directly relates to the degree of glucose tolerance. The treated animals received glucose at a rate of $4 \cdot 10 \pm 0 \cdot 01 \mathrm{mg} / \mathrm{min} / \mathrm{kg}$ body weight to maintain the glucose level $\left(\mathrm{G}_{1}\right)$ at $12.3 \pm 0.5 \mathrm{mmol} / \mathrm{l}$ and the untreated animals were infused with a lower glucose concentration $(4.01 \pm 0.07 \mathrm{mg} / \mathrm{min} / \mathrm{kg}$ body weight) and still had a higher $G_{1}$ glucose level $(13.8 \pm 0.7 \mathrm{mmol} / \mathrm{l})$. No significant impairment in glucose utilization of the animals in the present experiment was found.

The second steady-state blood glucose level $\left(\mathrm{G}_{2}\right)$ was calculated by averaging six blood samples taken over the 84 th to 104th minute. This reduced blood 


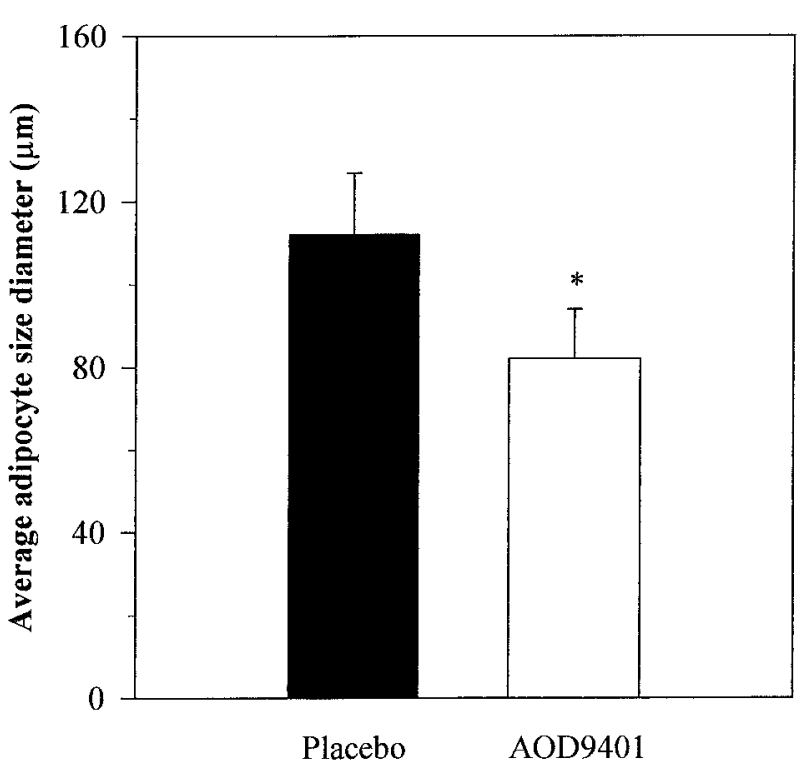

Treatment

FIGURE 4. Effect of AOD9401 on cell sizes of the adipocytes isolated from experimental animals treated either with AOD9401 implant or with placebo as described in Fig. 2. The cells were randomly selected and their cell diameters were measured. The results are means \pm s.E.M. of 120 cell size determinations for each group of animals. ${ }^{*} P<0 \cdot 05$ compared with the control group (Student's $t$-test).

glucose level, resulting from the responsiveness to infused exogenous insulin, is an in vivo physiological parameter, which could be used to evaluate insulin sensitivity of the animals. Both groups of animals were given the same rate of insulin infusion $(5 \cdot 98 \pm 0 \cdot 1 \mathrm{mU} / \mathrm{mg} / \mathrm{kg})$. However, the final steady state level of blood glucose was $12 \cdot 3-1 \cdot 1=11 \cdot 2 \mathrm{mmol} / 1$ for treated animals, and was $13.8-1 \cdot 2=12.6 \mathrm{mmol} / 1$ for untreated controls. Thus the same amount of exogenous insulin removed more circulating glucose from the blood in treated animals than in untreated controls. The present evidence suggests that treatment with AOD9401 did not affect insulin sensitivity or glucose tolerance of the animals under the experimental conditions as described. Recent glucose clamp experiments with an analogue compound (AOD9604) produced the same result $(\mathrm{Ng}$ et al. 2000). The plasma insulin levels of the experimental animals had not been measured as no significant effect of the AOD compound on the endogenous insulin levels had previously been detected in our obese mice studies.

\section{DISCUSSION}

It is well recognized that $\mathrm{hGH}$ is a multifunctional protein molecule with well-established lipolytic/ anti-lipogenic properties. We have recognized that discrete structural domains of the molecule may be responsible for specific metabolic functions of the hormone (Ng 1990). The present molecular studies of the lipolytic/anti-lipogenic domain (AOD9401) of the hGH molecule reveal that its in vitro actions in adipose tissues are identical to those of the intact hormone. The acute effects include the stimulation of HSL and inhibition of acetyl-CoA carboxylase in rat adipocytes. Consequently, an increase in lipolysis and a decrease in lipogenesis induced by AOD9401 in isolated segments of rat epididymal fat pads were observed. The lipolytic and antilipogenic actions of hGH have been well documented (Goodman \& Grichting 1983, Davidson 1987, Brummer \& Bengtsson 1995) although the precise molecular events involved in eliciting the metabolic changes remain largely unknown. Previous work from our laboratory has demonstrated that $G$ proteins play a role in the longer-term effects of growth hormone, and protein kinase $\mathrm{C}$ is involved in the acute effects of the hormone (Roupas et al. 1991, Kelly et al. 1994, Roupas \& Herington 1994). Treatment of rat adipocytes with $\mathrm{hGH}$ resulted in a transient and biphasic production of DAG which is present in signalling pathways involving both $\mathrm{G}$ proteins and protein kinase $\mathrm{C}$. Protein kinase $\mathrm{C}$ is involved in mediating the lipolytic action of hGH (Gorin et al. 1990). It has been well documented that one GH molecule interacts with two receptors (Postel-Vinay \& Kelly 1996), receptor dimerization provides the signal to generate the biological response of the target cells because it brings two Janus kinase (JAK2) molecules into close proximity, thereby facilitating transphosphorylation (Ymer et al. 1989). JAK2 phosphorylation leads to activation of a number of alternative signalling pathways. Activated JAK2 also induces the activity of MAP kinase and phospholipase $\mathrm{C}$ which results in hydrolysis of phosphatidylcholine to form diacylglycerol as a second messenger molecule (Rui et al. 1997). Interestingly, the small molecule, AOD9401, did not compete with ${ }^{125} \mathrm{I}-\mathrm{hGH}$ for receptor binding in a competition assay (Hefferman et al. 2000), but was shown to stimulate DAG production in adipocytes in a similar manner to intact GH. Rowlinson et al. (1996) has reported that the metabolic activities of some $\mathrm{GH}$ fragments are not mediated through hGH receptor. It is likely that $\mathrm{AOD}$ interacts with a cellular receptor other than $\mathrm{GH}$ receptor but stimulates similar downstream signalling events as 


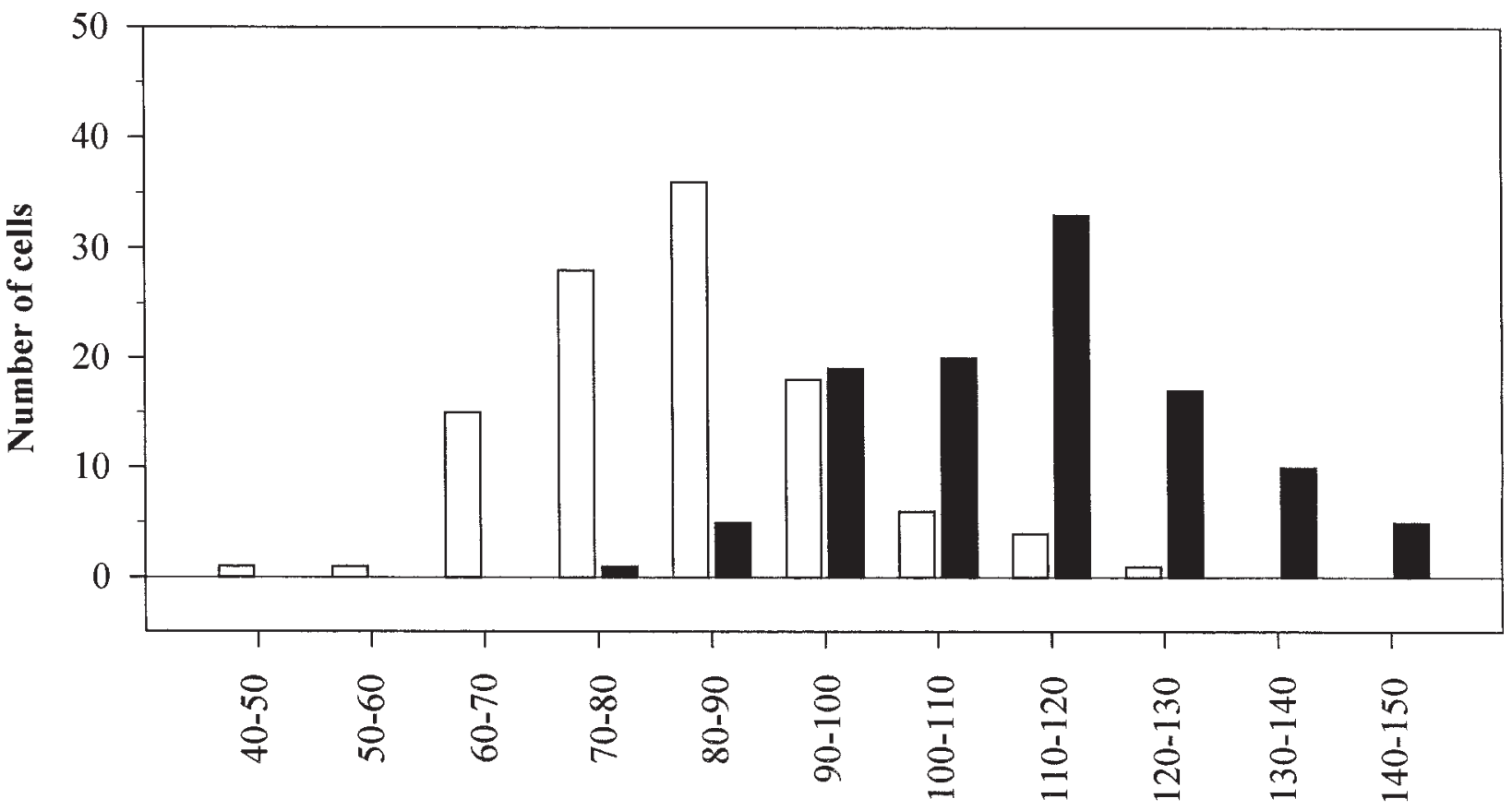

\section{Cell diameter (micrometers)}

FIGURE 5. Effect of AOD9401 on changes in cell size distribution of the adipocytes isolated from experimental animals after AOD9401 (open bars) or placebo (solid bars) implant as described in the legend to Fig. 2. A population of 120 cells was randomly selected and the distribution of their cell diameters was compared.

TABLE 3. In vivo effect of AOD9401 on blood glucose levels of Zucker fatty (fa/fa) rats. Animals were given different doses of AOD9401 i.v. Blood samples $(40 \mu \mathrm{l} / \mathrm{sample})$ were collected from the tail vein at the times indicated and whole blood glucose levels were measured immediately. Results are the changes (in $\mathrm{nM}$ ) from the respective basal values and are shown as means \pm s.E.M. of 4 animals in each group

Dose of AOD9401 ( $\mu \mathrm{g} / \mathrm{kg}$ body weight)

\begin{tabular}{|c|c|c|c|c|}
\hline \multirow{2}{*}{ Time (min) } & 0 & 250 & 500 & 1000 \\
\hline & & & & \\
\hline 0 & $0 \cdot 0 \pm 0 \cdot 0$ & $0 \cdot 0 \pm 0 \cdot 0$ & $0 \cdot 0 \pm 0 \cdot 0$ & $0 \cdot 0 \pm 0 \cdot 0$ \\
\hline 15 & $0 \cdot 1 \pm 0 \cdot 3$ & $0 \cdot 1 \pm 0 \cdot 3$ & $0 \cdot 2 \pm 0 \cdot 2$ & $0 \cdot 3 \pm 0 \cdot 2$ \\
\hline 30 & $0 \cdot 1 \pm 0 \cdot 2$ & $0 \cdot 2 \pm 0 \cdot 2$ & $0 \cdot 4 \pm 0 \cdot 2$ & $0 \cdot 6 \pm 0 \cdot 3$ \\
\hline 60 & $0 \cdot 1 \pm 0 \cdot 3$ & $0 \cdot 2 \pm 0 \cdot 3$ & $0 \cdot 2 \pm 0 \cdot 3$ & $0 \cdot 5 \pm 0 \cdot 3$ \\
\hline 120 & $0 \cdot 2 \pm 0 \cdot 3$ & $0 \cdot 1 \pm 0 \cdot 3$ & $0 \cdot 2 \pm 0 \cdot 3$ & $0 \cdot 4 \pm 0 \cdot 3$ \\
\hline 180 & $0 \cdot 1 \pm 0 \cdot 3$ & $0 \cdot 1 \pm 0 \cdot 3$ & $0 \cdot 2 \pm 0 \cdot 4$ & $0 \cdot 3 \pm 0 \cdot 4$ \\
\hline
\end{tabular}

There were no significant differences between any treated group and the control group.

the GH molecule in the generation of second messenger DAG. The molecular mechanisms of the regulation of lipid metabolism for both $\mathrm{GH}$ and $\mathrm{AOD}$ require further investigation, although the present studies show that AOD9401 acts in an identical manner to $\mathrm{GH}$, inducing DAG production in a similar biphasic pattern. The evidence so far is consistent with the concept that the carboxyl

www.endocrinology.org terminal region of the molecule is the lipolytic/ antilipogenic domain of $\mathrm{hGH}$ and is responsible specifically for the regulation of lipid metabolism of the hormone. Intact hGH stimulates hormonesensitive lipase activity in adipocytes, thus decreasing the lipid content of adipose tissue (Dietz \& Schwartz 1991). AOD9401, similar to the intact $\mathrm{hGH}$ molecule, activates the enzyme resulting in an 
TABLE 4. Effect of chronic treatment with AOD9401 on glucose metabolism in Zucker ( $\mathrm{fa} / \mathrm{fa}$ ) rats (360-370 g body weight). Animals were given a daily i.p. injection of AOD 9401 at a dose of $500 \mu \mathrm{g} / \mathrm{kg}$ body weight (b.w.) per day for 28 days. After treatment, the glucose tolerance and insulin responsiveness of animals were determined using the clamp technique. Results are means \pm s.E.M. of 4 animals in each group

\begin{tabular}{|c|c|c|}
\hline & Treated & Control \\
\hline \multicolumn{3}{|l|}{ Parameter } \\
\hline $\begin{array}{l}\text { Basal blood glucose level } \mathrm{G}_{0} \\
(\mathrm{mmol} / \mathrm{l})\end{array}$ & $8 \cdot 3 \pm 0 \cdot 1$ & $10 \cdot 4 \pm 0 \cdot 1$ \\
\hline $\begin{array}{l}\text { Rate of glucose infusion to achieve } \mathrm{G}_{1} \\
(\mathrm{mg} / \mathrm{min} / \mathrm{kg} \mathrm{b} \text {.w. })\end{array}$ & $4 \cdot 10 \pm 0 \cdot 01$ & $4 \cdot 01 \pm 0 \cdot 07$ \\
\hline $\begin{array}{l}\text { Difference of blood glucose level } \mathrm{G}_{1}-\mathrm{G}_{0} \\
(\mathrm{mmol} / \mathrm{l})\end{array}$ & $4 \cdot 0 \pm 0 \cdot 3$ & $3 \cdot 4 \pm 0 \cdot 1$ \\
\hline $\begin{array}{l}\text { Rate of insulin infusion to achieve } \mathrm{G}_{2} \\
(\mathrm{mU} / \mathrm{min} / \mathrm{kg} \text { b.w. })\end{array}$ & $5 \cdot 98 \pm 0 \cdot 01$ & $5 \cdot 98 \pm 0 \cdot 01$ \\
\hline $\begin{array}{l}\text { Difference of blood glucose level } \mathrm{G}_{2}-\mathrm{G}_{1} \\
(\mathrm{mmol} / \mathrm{l})\end{array}$ & $-1 \cdot 1 \pm 0 \cdot 3$ & $-1 \cdot 2 \pm 0 \cdot 1$ \\
\hline
\end{tabular}

There were no significant differences between any treated group and the control group.

increase in the lipolytic activity in the adipocytes and subsequently a reduction in the fat cell size. Our previous studies have unequivocally demonstrated the reduction of body weight gain of young obese mice after 18 days treatment with AOD9401. Data suggested that the body weight changes were due to the reduction of fat mass (Natera et al. 1994). C57BL/6J ob/ob mice are known to have markedly enlarged adipocytes due to diminished lipase activity (Herberg \& Coleman 1977). The present studies carried out with tissues from a different obese rodent model - fatty Zucker (fa/fa) rats - yield similar results. All these findings support the hypothesis that AOD9401 has no species specificity; it acts not only in obese mice but also in fatty rats.

The Zucker fatty rats implanted with slow-release tablets of AOD9401 were found to have reduced body weight gain as compared with the control animals over the 20-day experimental period. This significant reduction of body weight gain in the fatty rats is similar to our previously observed effect on obese mice under similar treatment with AOD9401 (Natera et al. 1994). For the present experiments, the discomfort and stress of the animals associated with daily injection were avoided. The present findings also reveal the feasibility of using different modes of AOD9401 administration for the same metabolic effect.

An increase in the lipogenic enzymes in adipose tissue of fatty Zucker (fa/fa) rats has been reported (Ellwood et al. 1985) and an elevation in lipogenesis in adipose tissues of young fatty rats is also generally known (Stern \& Johnson 1977). Our in vivo data are consistent with the notion that the elevated lipogenic activity in the treated fatty rats may be reduced by AOD9401. The ex vivo studies on the adipose tissues from the treated animals showed an inhibition of lipogenesis $16 \mathrm{~h}$ after implantation of AOD9401. The ex vivo evidence further supports the hypothesis that AOD9401 is the lipolytic/anti-lipogenic domain of the $\mathrm{hGH}$ molecule.

The diabetogenic effects of acute and chronic infusion of exogenous hGH are well known (Goodman \& Grichting 1983, Daughaday \& Harvey 1994) although the mechanism of these actions is not yet clear. Interestingly, the present study shows no change in insulin sensitivity in the fatty Zucker rats after daily intraperitoneal injection of AOD9401 at a dose of $500 \mu \mathrm{g} / \mathrm{kg}$ body weight for 28 days, as shown in the present glucose clamp experiments. The ability of the animals to respond to glucose load was not affected by the long-term treatment with AOD9401. The second steady-state blood glucose levels of animals, due to the effect of exogenous insulin infusion $(5.98 \mathrm{mU} / \mathrm{kg}$ body weight $/ \mathrm{min}$ ) were also without statistical difference between the two groups. The results suggest that the difference in diabetogenic status between AOD9401 and the intact hGH molecule may be due to the fact that the diabetogenic domain may reside in a different portion of the intact hormone. This further supports the concept that the multifunctional hGH contains a number of distinct structural domains for a wide spectrum of metabolic actions.

In conclusion, the present results demonstrate that AOD9401 has significant effects on the regulation of lipid metabolism. Both acute and chronic 
exposure of adipocytes, adipose tissue and animals to AOD9401 led to a shift 'downward' in lipid accumulation of the treated targets. A reduction in lipogenesis and a stimulation in lipolysis were observed. These alterations led to decreased rates of lipid storage in and increased rates of lipid mobilization from adipose tissue. These changes, in turn, led to the size reduction in adipocyte cell size and reduced body weight gain in the treated animals. On the other hand, results from the clamp experiments also revealed that AOD9401 did not induce any observable adverse effect on carbohydrate metabolism of the treated animals after chronic treatment. The findings in the present studies indicate that AOD9401 has the potential to be developed into a therapeutic agent for control of human obesity. On-going research to be reported elsewhere has produced evidence that human adipose tissues appear to be more responsive to the lipolytic/anti-lipogenic action of AOD9401 than that of porcine or rodent tissues in vitro (Heffernan et al. 1998).

\section{REFERENCES}

Adamafio NA \& Ng FM 1984 Effect of growth hormone in lipogenesis and glucose oxidation in genetically GH-deficient mice. Molecular and Cellular Endocrinology 37 241-244.

Bengtsson BA, Brummer RJM, Eden S, Rosen T \& Sjostrom L 1992 Effect of growth hormone on fat mass and fat distribution. Acta Paediatrica Scandinavica 81 62-65.

Bradford MM 1976 A rapid and sensitive method for the quantitation of microgram quantities of protein utilizing the principle of protein binding. Analytical Biochemistry 72 248-254.

Brummer RJM \& Bengtsson BA 1995 The effect of growth hormone on body composition. Asia Pacific Fournal of Clinical Nutrition 4 151-155.

Campbell PJ, Carlson MG \& Nurjhan N 1994 Fat metabolism in human obesity. American Fournal of Physiology 266 E600-E605.

Cardamone M, Lee RP, Lucas CJ, Birks DV, O'Donoghue M, Lofthouse SA \& Brandon MR 1998 Sustained-release delivery systems and their application for endoparasite control in animals. Fournal of Controlled Release 51 73-83.

Chase CI 1987 Testing differences between means. In Elementary Statistical Procedures, edn 3, pp 235-268. Singapore: McGraw-Hill.

Chretien M 1999 Clinical relevance of convertases: atherosclerosis, Alzheimer's disease, obesity, diabetes and HIV. Clinical and Investigative Medicine 22 207-211.

Coates PA, Luzio SD, Brunel P \& Owens DR 1995 Comparison of estimates of insulin sensitivity from minimal model analysis of insulin-modified frequently sampled intravenous glucose tolerance test and isoglycemic hyperinsulinemic clamp in subjects with NIDDM. Diabetes 44 631-635.

Daughaday WH \& Harvey S 1994 Growth hormone action: clinical significance. In Growth Hormone, pp 475-496. Eds S Harvey, GC Scanes \& WH Daughaday. Boca Raton: CRC Press.

www.endocrinology.org
Davidson MB 1987 Effect of growth hormone on carbohydrate and lipid metabolism. Endocrine Reviews 8 115-131.

Dietz J \& Schwartz J 1991 Growth hormone alters lipolysis and hormone-sensitive lipase activity in $3 \mathrm{~T} 3-\mathrm{F} 442 \mathrm{~A}$ adipocytes. Metabolism 40 800-806.

Ellwood KC, Michaelis OE, Emberland JJ \& Bhathena SJ 1985 Hormonal and lipogenic and gluconeogenic enzyme responses in LA/N-corpulent rats. Proceedings of the Society for Experimental Biology and Medicine 179 163-167.

Gliemann J 1965 Insulin-like activity of dilute human serum assayed by an isolated adipose cell method. Diabetes $\mathbf{1 4}$ 643-649.

Goodman HM \& Grichting G 1983 Growth hormone and lipolysis: a re-evaluation. Endocrinology 113 1697-1703.

Gorin E, Tai LR, Honeyman TW \& Goodman HM 1990 Evidence for a role of protein kinase $\mathrm{C}$ in the stimulation of lipolysis by growth hormone and isoproterenol. Endocrinology 126 2973-2982.

Harris DM, Dunshea FR, Baumen DE, Boyd RD, Wang SY, Johnson PA \& Clarke SD 1993 Effect of in vivo somatotropin treatment of growing pigs on adipose tissue lipogenesis. Fournal of Animal Science 71 3293-3300.

Heffernan M, Ogru E, Ignjatovic V, Gianello R, Jiang WJ \& Ng FM 1998 Sensitivity of human subcutaneous adipose tissues to the lipolytic activity of anti-obesity compound (AOD9401). International Fournal of Obesity $22 \mathrm{~S} 110$.

Heffernan MA, Jiang WJ, Thorurn AW \& Ng FM 2000 Effects of oral administration of a synthetic fragment of human growth hormone on lipid metabolism. American fournal of Physiology 279 E501-E507.

Herberg L \& Coleman DL 1977 Laboratory animals exhibiting obesity and diabetes syndromes. Metabolism 26 59-99.

Jeoung DI, Allen DL, Guller S, Yen V \& Sonenberg M 1993 Mitogenic and receptor activities of human growth hormone 108-129. Fournal of Biological Chemistry 268 22520-22524.

Jiang JW 1999 Investigation into human growth hormone 177-191 peptide and analogues as anti-obesity agents. $\mathrm{PhD}$ Thesis, Monash University.

Kelly PA, Goujon L, Sotiropoulos A, Dinerstein H, Esposito N, Edery M, Finidori J \& Postel-Vinay MC 1994 The growth hormone receptor and signal transduction. Hormone Research 42 133-139.

Kraegen EW, James DE, Bennett SP \& Chisholm DJ 1983 In vivo insulin sensitivity in the rat determined by euglycemic clamp. American Fournal of Physiology 245 E1-E7.

Lee M \& Schaeffer NK 1934 Anterior pituitary growth hormone and the composition of growth. Fournal of Nutrition 7 337-363.

Liberti JP 1981 Isolation and somatomedin activity of bovine growth hormone fragment 87-124. Biochimica et Biophysica Acta 675 239-247.

Lopez-Guajardo CC, Armstrong LS, Jordan L, Staten NR, Krivi GG, Martinez AO \& Haro LS 1998 Generation, characterization and utilization of anti-human growth hormone 1-43, (hGH1-43), monoclonal antibodies in an ELISA. Fournal of Immunological Methods 215 179-185.

McGowan MW, Artiss JD, Strandbergh DR \& Zak B 1983 A peroxidase-coupled method for the colorimetric determination of serum triglycerides. Clinical Chemistry 29 538-545.

Martial JA, Hallewell RA \& Baxter JD 1979 Human growth hormone: complementary DNA cloning and expression in bacteria. Science 205 602-607.

Morris AD, Shinchuo U, Petrie JR, Connell JMC, Elliott HL \& Donnelly R 1997 The euglycemic hyperinsulinemic clamp: an evaluation of current methodology. Clinical Experimental Pharmacology and Physiology 24 513-518. 
Natera SHA, Jiang WJ \& Ng FM 1994 Reduction of cumulative body weight gain and adipose tissue mass in obese mice: response to chronic treatment with synthetic hGH 177-191. Biochemistry and Molecular Biology International 33 1011-1021.

Ng FM 1990 Human growth hormone fragments. In New Antidiabetic Drugs, pp 197-205. Eds CJ Bailey \& PR Platt PR. London: Smith-Gordon Press.

Ng FM \& Bornstein J 1978 Hyperglycemic action of synthetic C-terminal fragments of human growth hormone. American Fournal of Physiology 234 E521-E526.

Ng FM \& Heng D 1988 Molecular interactions between human growth hormone and rat hepatic acetyl CoA carboxylase. Asia Pacific Communications in Biochemistry 2 47-51.

Ng FM, Sun J, Sharma L, Libinaka R, Jiang WJ \& Gianello R 2000 Metabolic studies of a synthetic lipolytic domain (AOD9604) of human growth hormone. Hormone Research (In Press).

Noma A, Okabe H \& Kila MA 1973 A new colorimetric micro-determination of free fatty acid in serum. Clinica Chimica Acta 43 317-320.

Orgu E, Wilson JC, Heffernan MA, Jiang WJ, Chalmers DK, Libinaki R \& Ng FM 2000 The conformational and biological analysis of a cyclic anti-obesity peptide from the C-terminal domain of human growth hormone. Fournal of Peptide Research 16 1-11.

Palidini AC, Pena C \& Retegui LA 1979 The intriguing nature of multiple actions of growth hormone. Trends in Biochemical Sciences 4 256-260.

Postel-Vinay MC \& Kelly PA 1996 Growth hormone receptor signaling. Baillieres Clinical Endocrinology and Metabolism 10 323-336.

Raben MS 1962 Clinical use of growth hormone. New England Fournal of Medicine 266 82-85.

Rosenbaum M, Gertner JM \& Leibel R 1989 Effects of systemic growth hormone administration on regional adipose tissue distribution and metabolism in GH-deficient children. Fournal of Clinical Endocrinology and Metabolism 69 1274-1281.

Roupas P \& Herington AC 1994 Postreceptor signaling mechanisms for growth hormone. Trends in Endocrinology and Metabolism 5 154-158.

Roupas P, Towns RJ \& Kostyo JL 1990 Isolated adipocytes from growth hormone-treated obese (ob/ob) mice exhibit insulin resistance. Biochimica et Biophysica Acta 1052 341-344.

Roupas P, Chou SY, Towns RJ \& Kostyo JL 1991 Growth hormone inhibits activation of phosphatidylinositol phospholipase $\mathrm{C}$ in adipose plasma membranes: evidence for a growth hormone-induced change in $\mathrm{G}$ protein function. PNAS 88 1691-1695.

Rowlinson SW, Waters MJ, Lewis UJ \& Barnard R 1996 Human growth hormone fragments $1-43$ and 44-191: in vitro somatogenic activity and receptor binding characteristics in human and nonprimate systems. Endocrinology 137 265-273.

Rui L, Mathews LS, Hotta K, Gustafson TA \& Carter-Su C 1997 Identification of SH2-beta as a substrate of the tyrosine kinase JAK2 involved in growth hormone signaling. Molecular and Cellular Biology 17 6633-6644.

Salem MAM \& Wolff GL 1989 Potentiation of response to insulin and anti-insulin actions by two human pituitary peptides in lean agouti A/a obese yellow Avy/A and C67BL/6J ob/ob mice. Proceedings of the Society for Experimental Biology and Medicine 191 113-123.

Stern JS \& Johnson PR 1977 Spontaneous activity and adipose cellularity in the genetically obese Zucker rats (fa/fa). Metabolism 26 371-380.

Stralfors P, Olsson H \& Belfrage P 1987 Hormone-sensitive lipase. In The Enzymes, vol 18, pp 147-177. Eds PD Boyer \& EG Kreb. New York: Academic Press.

Strobl JS \& Thomas MJ 1994 Human growth hormone. Pharmacological Reviews 46 1-34.

Tattersall R 1996 A history of growth hormone. Hormone Research 46 236-247.

Wade JD, Ng FM, Bornstein J, Pullin CO \& Pearce JS 1982 Effect of C-terminal chain shortening on the insulinantagonistic activity of human growth hormone 177-191. Acta Endocrinologica 101 10-14.

Waynforth HB \& Flecknell PA 1992 Intraperitoneal injection. In Experimental and Surgical Technique in the Rat, edn 2, pp 21-23. London: Academic Press.

Ymer SI, Stevenson JL \& Herington AC 1989 Binding sites for growth hormone in rabbit placental cytosol. Endocrinology 125 993-999.

Zucker LM \& Zucker TF 1961 Fatty, a new mutation in the rat. Fournal of Heredity 52 275-278.

REVISED MANUSCRIPT RECEIVED 23 June 2000 